\title{
It's difficult to be a man, but it's even more difficult to be an indigenous man: in/EXISTING masculine identities
}

\author{
María Alejandra Salguero-Velázquez \\ Facultad de Estudios Superiores Iztacala, Universidad Nacional Autónoma de México, \\ Ciudad de México, México.
}

Translated by Dania Isabella Tabares Castañeda*Universidad del Valle, Cali, Colombia.

Received: February 22nd 2018. Approved: April 1st 2018.

DOI: $10.25100 /$ lamanzanadeladiscordia.v13i1.6735

Traducción

\begin{abstract}
This article deals with the complex processes of identity construction in indigenous men. By incorporating the concept of "In/EXISTING identities" it seeks to account for a process that takes place in a contradictory manner. The prefix "in" intends to indicate both the existence and nonexistence of indigenous masculine identities that often "disappear" as in the case of the forced disappearance of the Azyotzinapa students in 2014. International law links the marginalization of indigenous peoples in the Americas to the lack of recognition of their rights, undermined by Western ethnocentric principles based on a notion of "white, blond, strong, successful manhood". A feminist approach, calling for the fight against hierarchies and inequalities, and the giving of voice to "minorities" is incorporated, along with a concept of justice as a principle that requires equal opportunities for everyone regardless of sex, race, or ethnic group. Social inequalities are examined as historical and social constructions. Being a man is learned, and re-learned through complex socialization processes that in the case of indigenous identities require identifying Western constructs. Indigenous men experience such processes under conditions of economic, political, and sociocultural inequality, reaffirming their generic ethnicity in subaltern conditions. Some struggle to re-signify; others die trying.
\end{abstract}

Keywords: Masculinities; indigenous; identities; gender.

\section{In/EXISTING identities}

One of social sciences' commitment is to both think about and carry out social change. A case in point is the disappearance of the Ayotzinapa students. In order to account for a process articulated in a contradictory manner - the simultaneous existence and inexistence of indigenous people in a discriminatory and unequal world -this article incorporates the concept of "In/EXISTING Identities". International Law acknowledges that the marginalization of indigenous people in the Americas is the product of a lack of recognition and respect for their rights. According to Alma Dzib-Goodin (2016) on October 2 of that year, the Mexican government aired a radio spot about indigenous peoples' rights. A speaker with a certain accent, in whose voice one can hear the commitment to indigenous rights read the message. As in other similar messages, there is extreme clarity, "we are all willing to respect indigenous peoples' rights, we all agree with that! Don't

*Estudiante de décimo semestre de Licenciatura en Lenguas Extranjeras (Inglés-Francés) de la Universidad del Valle (Cali, Colombia). Correo electrónico: dania.tabares@correounivalle.edu.co. 
we?" Although the message was aimed at indigenous people, it was broadcasted in Spanish, not in any indigenous languages. How is this not a contradiction? What of indigenous people? If their capacity for expressing themselves is limited in the media and their voices are not allowed to be heard or their accents recognized, this can only be a contribution to their extinction. While their craftworks are highly valued abroad, here, in Mexico, we bargain and pay the cheapest prices. Why is Mexico embarrassed of its cultural richness? Why do we not give a voice to those people who have rights? Why are these rights only declared in Spanish? Is it not contradictory? Martínez (2003) considers that "in the topography of modern identities, indigenous peoples have never existed. Thus, what has not existed cannot be recognized, and what cannot be the object of recognition lacks, ultimately, identity" (p. 9). We could ask ourselves, where does this lack of recognition come from? Could it be that indigenous identity does not comply with the Western standards of certain institutions? Seidler (2000) and Amorós (2000) have already questioned Western-influenced knowledge, even so-called scientific knowledge, that validates only a certain kind of knowledge based on Cartesian anthropocentric, ethnocentric and androcentric principles. Such knowledge only strengthens a particular vision of masculinity: that of white, rational, self-contained manhood, whose goal is to exert power and control over others.

\section{Feminist approach}

Feminism provides a way to open the debate, since it does not only call for women but also for men in the search for options against the hierarchies and inequalities between genders. In the struggle to transform society, it is a theoretical and political standpoint that incorporates dimensions not considered before such as family, sexuality, personal relations, and daily life. De Barbieri (1986) believes the slogan should be to change life at the material level, in the public sphere, in the exercise of citizenship, and in the private sphere of the family, marriage, upbringing, sexuality, and affections.

One of the fields where meaningful achievements have been attained through gender perspective is the field of women, and nowadays, men studies. Sev- eral social sciences paradigms have been revised and new categories created to identify and articulate conflicts in men-women relationships, as well as class, and ethnic inequalities. De Barbieri (1986) points out that there are essential convergence points between the movements that emerged in the sixties like those of human rights activists, ecologists, pacifists, young and old people, feminists and ethnical majorities and minorities. Foremost among them is the defense of the inalienable and imprescriptible rights of all individuals, including the right to be different and to self-determination, as long as these are not detrimental to others. This implies respect for ideas, beliefs and the organization of daily life according to what people hold convenient; it also implies the right to manage affections according to people's wishes. González (1989) claims that feminism has transformed the way we understand and "do" politics by restoring the political dimension to daily life. When feminism states that what is personal is also political, it highlights problems that from a traditional, political scope had been set aside because they were considered to be secondary. This scope kept a comfortable and unquestionable separation between what is "private" and "public", between "private life" and "public life". According to feminism, both must change, and this change does not depend only on women, it also includes men. Bodelón (1988) shows how the question of equality is studied in contemporaneous feminist thinking, based on the convergence of political, legal, and social theory. Defined as just another social aspect, or as a purely legal or political topic, it is easy to see the narrowness that is produced when an issue is not described in socio-historical and cultural terms. Justice requires equal opportunities for all individuals regardless of gender, race or ethnic group.

In the late seventies, a big part of the feminist movement started to reconsider the limits of the traditional definition of equality so as to understand difference as something other than an ideology to legitimize exclusion. Implicitly, social movements that state a positive meaning of difference, do so based on a democratic and pluralistic view of society, in which the objective is not to eliminate difference in itself, but the idea of subordination. We need to rethink equality so that it eliminates social 
inequality by incorporating the "differences" between men and women as individuals with their own identities, needs and affections.

Equality for men and women regardless of social or ethnical condition as well as hegemonic spaces and powers must be open to debate. Nowadays, the needs of women, men and "minority" groups such as indigenous people are meaningful and important; the principle of equality should incorporate them rather than just tolerate them. One possibility would be to advance the concept of substantial equality whereby existing differences between people are taken into account, giving them the same rights and valuing them for who they are as individuals.

In Mexico, even though the Constitution establishes in its fourth article complete legal equality between men and women, the truth is that inequality is still present in many social institutions both in the private and public realms, reproducing all kinds of disadvantages for both men and women. This constitutionally established principle has not prevented dissimilar logics regarding sexual roles, many of which are supported by assumptions of a naturalistic and essentialist order, which can be generically deconstructed. Another option is De Sousa's (2009) proposal for Latin America concerning the use and validation of an epistemology from the South, that accounts for the voices of Latin American subjects, giving visibility to people and social groups that have been historically exploited and oppressed by global colonialism and capitalism. Speaking from the "South" and making the "South" visible will imply not only exposing but also deconstructing oppressive conditions like gender and ethnicity as the historical and social processes they are.

In the same way, Pérez-Nasser (2011) and Díaz-Cervantes (2014) suggest the incorporation of feminist approaches that emphasize a gender perspective, particularly the relationship between ethnicity and gender, in order to understand historical processes that intervene in the construction of the contemporaneous indigenous subject, rendered invisible and oppressed by the stereotypes of a hegemonic masculinity that tends to subjugate and dominate indigenous identities.

\section{A gender view}

Gender allows us to analyze and comprehend the particularities that define men and women in a specific way, recognizing their similarities and differences. Through gender it is possible to examine the complex and diverse relationships that exist between genders, their different views of life, expectations and opportunities, as well as the conflicts they face on a daily basis with institutions and the way they deal with these problems. In particular, it is possible to understand what meanings men and women give to the events they experience, specifically how indigenous men signify and live out their masculine condition. One way to go about this is to incorporate as a theoretical and methodological axis the historicity in the sociocultural construction of the subject in contrast with other philosophical postures that think of human beings as as given, eternal and immutable, where differences between men and women or even between men are considered "natural" or biologically determined through generalizations and universalizations. Many of these assumptions are inscribed within the inherited ontological logic. Castoriadis (1988) points out that the logic of determination has been supported by a tradition associated to what is physical, reducing society and history to the biological nature of human beings, of which the most representative case is functionalism. This theory conceives fixed human needs and explains social organization as the set of functions that tend to fulfill them, concealing the fact that since human needs are not merely biological but social as well, they are inseparable from their objects, so that society determines both the needs and the objects. Formal logic entails a linear, deterministic, binary, selective thinking, establishing univocal principles of cause and effect relations, often positing a single cause at the origin of complex phenomena. Lewontin, Rose \& Kamin (1991) consider that from this view there derives philosophical postures that prevail even today, permeating a big part of scientific knowledge which is then somehow "framed" inside a particular way of seeing and conceiving both the world and human beings. Two different approaches account for this posture: the first one is reduction- 
ism, which includes a series of general methods and modes of explanation of the world of objects and human societies that attempts to explain complex realities based on particularities, thus giving circular and closed explanations. The second one, conceived as a special case of reductionism, is biological determinism, which bases its explanations on the inevitability of the biochemical properties that constitute the individual, determined as they are by the genes that every individual possesses.

These postures have given place to the creation of self-recreating myths. One such myth is about the instinctive nature of conduct. The origin of behavior from a reductionist perspective would indicate that "it is inherited rather than acquired". Under this vision of biological determinism, it is only possible to find reductionist explanations for human life, where causality flows from genes to human beings and from individuals to society. Several forms of slavery, exploitation, repression and genocide have been justified with arguments centered on biological inferiority.

In some areas of knowledge, explanations about the differences between men and women or between human groups are still advanced and contrasted as universal biological principles of human behavior even though they are based on physical appearance or IQ criteria. As Siedler (2000) has pointed out, incorporating the concept of ethnicity allows for a confrontation of the biological conception of gender stereotypes that support the universalism of the Western white, European, heterosexual subject. Many of the "differences" between men and women or among men themselves have to do with the reductionist and determinist theories inside a model of science that is the end-result of the kind of bourgeois capitalist and patriarchal society that developed from the 17 th century until today. The emphasis that patriarchal science places on objectivity, reasoning and the understanding of nature through its domination, is the product of the separation between reason and emotion, objectivity and subjectivity, a distinction that can only provide us with a partial knowledge of events.

In connection with the above, Díaz-Cervantes (2014) proposes adopting gender perspective as an epistemological, theoretical and methodological po- sition in order to understand the relational, diverse and complex character of the indigenous subject, placing modern indigeneity as part of a constant and conflictive socialization process between Western symbolic systems and the collective resistances that go into the construction of modern indigenous identity. This approach seeks to overcome gender dualism, as well as naturalistic determinism while focusing on the processes of social construction that reveal the differences between masculinity and being a man in sociocultural practices inside gender as a sociocultural code as Connell (2015) has explained.

Indigeneity marks an important difference in the construction process of being a man as considered by Guillermo Núñez in his books Vulnerable Lives (2009) and Sonora Men (2013). Núñez points out that there are meaningful differences in terms of power relations among men based on social class, ethnic group, sexual preferences, educational level, occupation, and rural/urban origin, among others. In that sense, we can point out that the social construction of gender is more diverse, despite the homogenization that some intend to make out of the concept of "man". We would have to ask ourselves: which man? And from which historical period, sociocultural group, generation, or family structure?

In Mexico, Nava (1996), Hernández (1996), Rojas (2000), Gutmann (2000), Salguero (2002), Jiménez (2003), Salguero \& Pérez (2008; 2011), Figueroa \& Salguero (2014) as well as in Latin America, Valdés \& Olavarría (1998), Fuller (2000), Viveros (2000), have carried out research where they provide accounts of the diversity of meanings and practices for being a "man" and the way these are exposed to a series of contradictions.

\section{Indigenous identities: construction process in so- ciocultural practices}

A diverse viewpoint must accompany our approach to indigenous masculine identities, their meanings and practices, their resistances and adaptations to the Westernized processes of socialization and their strategies of survival and reproduction.

The construction of indigenous masculine identities is closely related to sociocultural practices such as family, work, community, where there can be elements of subalternization that are learned 
and performed according to Butler (2012), and updated in the kind of participation that men carry out through their daily activities, generally under precarious, impoverished, marginalized, discriminatory and unequal conditions. These conditions are inherited through colonization processes and reproduced in daily practices, in interactions with others, and in the recognition or sanction and constant questioning of their performance as indigenous men. In the words of Ole Dreier (1999), indigenous fragility or vulnerability refers to the socioeconomic, political and cultural positioning that has been assigned to indigenous peoples in Mexico and Latin America in a historical, circumstantial and structural way.

Díaz-Cervantes $(2003 ; 2012)$ considers that several processes, some of them, far-reaching ones, have permeated indigenous subjectivity, its organization and interactions. An example of this is the colonization process where the indigenous subject was forged based on the stereotype of the "brute" or the "savage". This position justified their Judeo-Christian indoctrination and even their extermination. Later on, during the two hundred years of the modern nationstate, indigenous people were subjected to an 'educational' process conducted along liberal ideology, and more recently, globalization. In this context, Turner (1999) considers that indigenous peoples are still undervalued, stigmatized and excluded.

Government and religious institutions for the most part have implemented some of the complex learning processes about ethnicity among indigenous peoples. These initiatives have imposed stereotyped models of what it means to be a man or a woman, to create a family and a community. Masculine supremacy and power have been legitimized based on these models.

From a gender perspective, it is necessary to discuss the construction and learning processes in indigenous men and women of gender sociocultural practices through which they learn the ways of being in the world, and in particular, the ways of being indigenous. Nonetheless, it is also necessary to incorporate the possibility of processes of deconstruction and otherness in the construction of new identities. Pérez-Nasser (2011) accounts for generational transformation processes dealing with the meanings and practices of masculinity and indigenous men among Nahua groups of the Sierra Norte of Puebla.

\section{You learn to be a man and then you learn again}

The lives of men, in plural, since there are multiple ways of being a man, are intertwined in the weaving of meanings that they build according to the place where they live, the beliefs they hold and their lifestyles. The historical construction of gender was revealed by Simone de Beauvoir (1977) when she pointed out "One is not born, but rather becomes, a woman". Following this statement, it is possible to affirm that one is not born, but rather becomes, a man. One becomes a man using the material and symbolic resources at hand, which are conditioned by social, economic, political, ethnic, educational and family environments and depend on the particular stage of one's life trajectory.

When it comes to men, it is possible to say that they move through continuous learning processes of gender stereotypes, that are usually characterized by aggressiveness, violence, authority, power exercise, scarce manifestation of affection and feelings, among others (Gutman, 2000; Salguero, 2014). This learning process is incorporated through language, attitudes and ways of performing. Every sociocultural group elaborates, through its different institutions, worldviews about what "men are or should be". Based on their history and their national, popular, community and generational traditions, sociocultural groups incorporate norms, duties and prohibitions about the life of men. From an early age, men learn to identify themselves with certain gender attributes. However, in their life trajectory, they also incorporate some changes regarding their values, norms and actions as men.

When we explore the lives of men and what it means to be a man, and take their voices as a point of departure, we find that these notions integrate a diversity of meanings that are often contradictory. Meanings change depending on the particular stages of life trajectories, and on the conditions, circumstances and resources at hand. Meanings are not fixed; they are constructed and reconstructed. For some, "being a man" means to take the initiative, to have goals, to provide economically - even if their partners also provide — to be the one who takes 
responsibility and takes care of the family, wife and kids, the one who must solve everything. This learning integrates a long relation process, not only with fathers but also with mothers, brothers, sisters, classmates, and friends; some of them even mention that they learned how to be a man from their romantic partners (Salguero \& Pérez, 2008; 2011).

The above is an invitation to reflect beyond the hegemonic model that sets the often-stereotyped standards of identity of what it means to be a man. A man who does not express emotions or feelings, a man that is active, autonomous, strong, virile, heterosexual, the head of the family and a good father. These are stereotyped constructions that can hardly be attained, a situation that in turn creates more difficulties and confusion not only in the personal field but also in the academic and research field (Amuchástegui, 2006; Clatterbaugh, 1998; Seidler, 2000).

Masculinity cannot be analyzed in an abstract way. Gutmann (2000), Salguero (2013) and Connell (2015) point out that masculinity has to be considered as a process, placing it in the contexts where men participate, according to the different stages of their life trajectories, taking into account the forms of participation of men as a procedural movement and not as something fixed and determined beforehand in a particular way. Just as feminism stated the impossibility of speaking about femininity or women in an abstract way because of the existence of several conditions such as class, age, sexual orientation, that shape different identities, the same can be said about masculinities and men. What we should analyze here are the diverse identities through which a way of being a man and of being a person is articulated.

It is necessary to account for the diverse processes through which men construct a particular type of man, not in an indefinite, abstract way nor in an isolated manner, but in the collective construction of meaning built into their identities. It is in those other identities, such as being a father, where being responsible gains meaning. In being a partner or in forming a family, a certain way of being a man and a person is achieved. It is in these roles, and not only in the performance or non-performance of certain activities, but in the emotional, corporal and time implication with sons, daughters, partners, or at work where such identities are established. Ultimately, this allows men to become a particular type of man/partner/father/worker, not as independent stages or steppingstones, but as part of an integrated whole struggling and making efforts to evolve into a man. Thus being a man is a way of becoming, never a mere way of being (Pérez, 2011; Salguero, 2013).

\section{Being a man through diverse identities}

From the perspective of cultural psychology and gender, one way of approaching this conceptual problem is to identify and account for the process of identity formation in indigenous men as a free flowing, complex, diverse and changing one. Conceptually, we have to account for the way in which a diversity of practices and meanings that men build in the procedural flux of their life trajectories are articulated, where they construct diverse identities such as son, partner, father, student, worker — that are not homogenous in the way they appropriate or challenge hegemonic gender stereotypes.

This perspective implies viewing masculinity as a complex configuration of identities that is not accomplished all of a sudden, but through multiple relations and positions in diverse contexts; at the same time, this requires confronting the tensions that those multiple participations pose where subjects incorporate their own point of view and that of others, achieving thereby a relative and provisional integration that, nonetheless, is meaningful at a personal level. In this view, it is necessary to address relational processes and dynamism, without giving priority to any identity (son, partner, father, worker, among others). Research work has to reconstruct the process through which, starting from certain identities and stages in life, men recognize and confront the tensions and incongruities between ways of being an indigenous man in different practical contexts and what these mean for the partial reproduction, challenge and search for alternatives to gender stereotypes.

Furthermore, we have to account for the multiple forms of relations that men construct every day in the different processes of interaction where they estab- 
lish forms of identity, keeping in mind that identity is temporary and situational, not fixed nor finished but a part of a continuous process (Wenger, 2001).

In this sense, identity as a man is not achieved in an abstract way, but in the negotiation and articulation of other identities such as father, husband, brother, partner, etc. It is through these identities where the forms of participation give sense and meaning to a man's life. Manhood becomes part of a process of continuous development where tensions and conflicts are often present because of masculine and feminine gender stereotypes, since socially speaking, there are spaces, activities and generic forms of relation, which are sometimes dichotomous and exclusive based on what a man "should be" according to norm. Based on these historically constructed meanings indigenous men face the process of creating a family, where they construct their personal stories and give sense and meaning to their lives. Weber (1988) points out that the world we live in is a world whose sense and meaning are constructed by us and the human beings who preceded us. Thus, the understanding of meanings provides a way of living and being in the world. It is possible to live and be in the world in multiple ways, as a man, father, professional, worker, friend, heterosexual, homosexual, among others. What matters is to identify how and with whom those meanings are negotiated, since it is in the social practices where historical productions appear, not only in terms of the meaning of practices (family, community, job, paternity), but also of the person's history, in time, space, and in local practice, through diverse forms of negotiation and permanent struggles that can either take or not take place. That is how people construct their own history (Holland, Lachicotte, Skinner \& Cain, 1998).

The social participation of indigenous men in the world has been part of the social inequalities where the processes of negotiation are absent. Nevertheless, developing or constructing an identity incorporates a dynamic and historical process, through certain forms of participation. Constructing identities means negotiating the meanings of our experience through practice, negotiating ways of becoming a person in a particular context. This negotiation can be silent; people can either talk or not talk about it, but regardless of whether they address it or not, they unfold it in their way of engaging in action and interacting with each other.

In the case of men, they relate and participate in more than one context of action such as family, job, friends, community, (Salguero, 2014). Men participate as partners, fathers, workers, friends, engaging in different ways, a process which allows them to construct complex identities that they later integrate and define based on their engagement with each of those practices. This engagement implies relations with others (wife, kids, job, friends) and therefore the capacity of relating meaningfully with what they do or do not do (dedicate more time to family, to work or to friends) through a diverse and complex process, that is sometimes conflictive while attempting to compensate, balance or even end their relationships as partners, fathers, workers, and friends.

In this way, it is possible to affirm that indigenous men gradually become a certain type of person based on the concrete way in which they participate in the sociocultural practices of being a partner, father, employee, friend, or in leisure activities, among others, getting involved at the same time in complex learning processes in which said identities are shaped. This in turn is part of the endless process of becoming a certain type of man, struggling and making an effort to become that man. This can only be conceptualized as a way of becoming, never a mere way of being (Holland \& Lave, 2001). Based on this, it can be stated that men do not exist in an abstract way but inside a certain type of social configuration and as a particular type of people, unfolding diverse identities, which, as Burke (2003) points out, will be part of the society creation and re-creation process in which said identities are embedded.

Identities are not constructions a priori to our socialization, neither are they found inside our head, nor introduced only through our experience; they abide and are forged in the relational weft, in the space of life, in the social scheme, in the constituting and constituted symbolic magma of every social being (Doménech \& Ibañez, 1998).

It is in the participation of certain social practices where identities are forged and articulated. Pérez (2011) points out that no identity exists in isolation from others, as if it were determined by 
the immediate context of its unfolding. A man is not only a partner or a father, but also a son, brother, friend, or worker in other contexts and with other groups of people with which he negotiates said identities through his forms of participation. Most of the time, men will have to make efforts and negotiate in order to articulate said identities through the practices in which they participate. Ideological discourses based on gender, such as the idea that men's primal activity is work and that their primal role is to provide economically, even while their female partners also do so, inevitably surface. Yet it is currently more and more necessary that men relate with their sons and daughters (Salguero, 2007). However, allocating time for family, home activities and kids is something that in some contexts is simply unthinkable.

\section{It is difficult to be a man, but it is even more dif- ficult to be an indigenous man}

This is so because of the processes of social construction where vulnerability and social exclusion are incorporated through experience (Larrosa, 2006) in daily life and embedded in a "naturalized" way as part of the process of social construction (Berger \& Luckmann, 1997). Disadvantages are incorporated and embedded as something natural through socialization processes: "I am poor and I am indigenous, I cannot have access to anything else". This is learned and incorporated everyday through social discourses and practices. It is learned in families, in workspaces, community relationships, with friends, in schools and in health institutions.

This socialization process is continuous and imperceptible. It is learned it through symbols, gestures, modes of expression and differentiated actions. It is internalized from childhood in the relations of submission and dependence that men establish with their mothers and fathers, to such a degree that in some families, they still treat each other using the "usted" form of address, which conveys respect but also incorporates status and inequality. It is reinforced in adolescence and it is perpetuated and transmitted in adulthood to the new generations.

Inequalities, lack of rights and inequities are learned and embedded, perpetuating differences between those who have social status and those who do not, those who are recognized because of their skin color or type of hair and those with Westernized traits according to the hegemonic model of masculinity. In this way, one learns what it means to be a man, but not necessarily an indigenous man.

This is why the discussion and analysis of the internalization of socialization processes becomes important. It is through these processes that men incorporate what it means to be a man, and more specifically an indigenous man.

Recalling Díaz-Cervantes'(2003; 2014) statement, it is necessary to point out, without trying to underestimate the difficult situations that indigenous women experience, that it is important to recognize and reveal that men also go through serious issues that need to be discussed and dealt with. Several masculinity studies have shown that men take on leadership roles such as those of providers and domestic and community leaders under precarious resource conditions such as low-pay work or low productivity. This makes it difficult for them to perform well in such positions and roles, thus creating negative consequences for them and those they live with.

Manliness in terms of identity construction is perceived as distant and non-emotional; silencing it has led men to endure physical and emotional discomforts. Sensitivity, tenderness and caring for others have been disqualified by other men and sometimes even by some women because they are associated with weakness: this creates frustration, discomfort and fear (Figueroa, Jiménez \& Tena 2006; Figueroa \& Nájera, 2015).

For Núñez (2009), not all men have a privileged position. Many of them are oppressed, discriminated by other men and women, denied not only their symbolic rights as men, but also their dignity as humans. Racist, homophobic, classist and gender discourses divide and classify men according to their symbolic power, disqualifying and undervaluing the identity of some men, especially that of indigenous men.

Addressing the study of the discomfort and difficulties of indigenous men from a gender studies perspective has generated questioning from some academic fields, even feminist ones because of the accepted idea that conceives men as the main 
beneficiaries of the patriarchal order, a fact enunciated by Cornell (2015). This represents yet another challenge since we must overcome theoretical and methodological barriers from academia itself. One possibility is to continue giving voice to men as Jiménez (2003) has pointed out, and in particular to indigenous men.

\section{Bibliographic references}

Amorós, Celia. (2000). Feminismo y filosofía. Spain: Síntesis.

Amuchástegui, Ana. (2006). ¿Masculinidad(es)?: Los riesgos de una categoría en construcción. In Gloria Careaga \& Salvador Cruz (Coords.), Debates sobe Masculinidades (pp. 159-181). Mexico: Programa Universitario de Estudios de Género, Universidad Nacional Autónoma de México.

Berger, Peter \& Luckmann, Thomas. (1997). La construcción social de la realidad (Silvia Zuleta, Trans.). Buenos Aires: Amorortu editors. (Original work published in 1968).

Bodelón, Encarna. (1988). La Igualdad y el movimiento de mujeres: propuestas y metodología para el estudio del género. Spain: Instituto de Ciencias Políticas y Sociales, Universidad Autónoma de Barcelona.

Burke, Peter. (2003). Advances in identity theory and research. England: Kluwer Academic and Plenum Publishers.

Butler, Judith. (2012). Deshacer el género (Patricia Soley-Beltran, Trans.). Spain: Paidós Studio. (Original work published in 2004).

Castoriadis, Cornelius. (1988). La institución imaginaria de la sociedad. Volumen 2: El imaginario social y la institución (Antoni Vicens, Trans.). Barcelona: Tusquets. (Original work published in 1975).

Clatterbaugh, Kenneth. (1998). What is problematic about masculinities? Men and Masculinities, 1(1), 301-330.

Connell, Raewyn. (2015). Masculinidades. Mexico: Programa Universitario de Estudios de Género, Universidad Nacional Autónoma de México.

De Barbieri, Teresita. (1986). Movimientos feministas. Grandes tendencias políticas contemporáneas. Mexico: Universidad Nacional Autónoma de México.

De Beauvoir, Simone. (1977). El segundo sexo. Los hechos y los mitos. Tomo I: La experiencia vivida (Pablo Palant, Trans.). Buenos Aires: Ediciones Siglo Veinte. (Original work published in 1949).

De Sousa, Boaventura. (2009). Una epistemología del Sur: la reinversión del conocimiento y la emancipación social. Mexico: Siglo XXI.

Díaz-Cervantes, Rufino. (2003). Identidades de género y crisis de masculinidades en comunidades rurales de
Michoacán, Puebla y Tlaxcala. In Beatriz Martínez \& Rufino Díaz-Cervantes (Coord.), Mujeres rurales, género, trabajo y transformaciones sociales (pp. 117158). Puebla: Colegio de Postgraduados.

Díaz-Cervantes, Rufino. (2012). Etnia, género y migración en la (re)significación masculina y sobrevivencia Xi'oi-pane (Doctoral thesis). Universidad de Deusto, País Vasco, Spain.

Díaz-Cervantes, Rufino. (2014). La perspectiva de género en la comprensión de la masculinidad y la sobrevivencia indígena en México. Agricultura Sociedad y Desarrollo, 11(3), 359-378.

Doménech, Miguel \& Ibáñez, Tomás. (1998). La psicología social como crítica. Revista Anthropos. Huellas del Conocimiento, (177), 12-21.

Dreier, Ole. (1999). Trayectorias de participación a través de contextos de práctica social. Psicología y Ciencia Social, 3(1), 28-50.

Dzib-Goodin, Alma. (2016). La voz de los indígenas no es la voz de todos. RevistaEduc@rnos. Retrieved from https://revistaeducarnos.com/la-voz-de-los-indigenas-no-es-la-voz-de-todos/.

Figueroa, Juan \& Nájera, Jessica. (2015). El uso de las autopsias verbales para analizar algunos suicidios de varones progenitores. Acta Universitaria, 25(2), 1925. doi: 10.15174/AU.2015.848.

Figueroa, Juan \& Salguero, Alejandra. (2014). ¿Y si hablas desde tu ser hombre? Violencia, paternidad, homoerotismo y envejecimiento en la experiencia de algunos varones. Mexico: El Colegio de México.

Figueroa, Juan; Jiménez, Lucero \& Tena, Olivia. (2006). Ser padres, esposos e hijos: prácticas y valoraciones de varones mexicanos. Mexico: El Colegio de México.

Fuller, Norma. (2000). Significados y prácticas de paternidad entre varones urbanos del Perú. En Paternidades en América Latina (pp. 35-90). Peru: Fondo Editorial, Pontificia Universidad Católica del Perú.

González, Maruja. (1989). ¿Qué es el feminismo? Breve historia y aproximaciones teórico-políticas. Cuadernos para la mujer, (2), 5-37.

Gutmann, Matthew. (2000). Ser hombre de verdad en la Ciudad de México. Ni macho ni mandilón. Mexico: El Colegio de México.

Hernández, Daniel. (1996). Género y roles familiares: la voz de los hombres (Masters thesis). Centro de Investigaciones y Estudios Superiores en Antropología Social, México.

Holland, Dorothy; Lachicotte, William; Skinner, Debra \& Cain, Carole. (1998). Identity and agency in cultural worlds. Cambridge: Harvard University Press.

Holland, Dorothy \& Lave, Jean. (2001). History in person. In History in person. Enduring struggles, contentious practice, intimate identities (pp. 3-33). Santa 
Fe, New Mexico: School of American Research Press. Jiménez, María. (2003). Dando voz a los varones. Sexualidad, reproducción y paternidad de algunos mexicanos. Mexico: Universidad Nacional Autónoma de México.

Larrosa, Jorge. (2006). Sobre la experiencia. Separata. Revista de educación y pedagogía, 17, 43-51. Retrieved from http://aprendeenlinea.udea.edu.co/revistas/index.php/revistaeyp/article/view/19065/16286.

Lewontin, Richard; Rose, Steven \& Kamin, Leon. (1991). No está en los genes. Racismo, genética e ideología (Enrique Torner, Trans.). Mexico: Crítica. (Original work published in 1987).

Martínez, Asier. (2003). Los pueblos indígenas y el discurso de los derechos. Bilbao: Instituto de Derechos Humanos, Universidad de Deusto. Retrieved from http://www.deusto-publicaciones.es/deusto/pdfs/ cuadernosdcho/cuadernosdcho24.pdf.

Nava, Regina. (1996). Los hombres como padres en el Distrito Federal a principios de los noventa (Masters thesis). Universidad Nacional Autónoma de México, Mexico.

Núñez, Guillermo. (2013). Hombres sonorenses. Un estudio de género de tres generaciones. Mexico: Pearson.

Núñez, Guillermo. (2009). Vidas vulnerables. Hombres indigenas, diversidad sexual y VIH/SIDA. Mexico: CIAD A.C. and Edamex.

Pérez, Gilberto. (2011) ¿Qué es el desarrollo psicológico? Una propuesta desde una perspectiva sociocultural. In Gilberto Pérez \& Juan Yoseff (Coords.), El desarrollo psicológico desde un enfoque sociocultural (pp. 4-25). Mexico: Universidad Nacional Autónoma de México.

Pérez-Nasser, Elia. (2011). Dificultades y contradicciones en la configuración de las identidades nahuas de tres generaciones de hombres de la Sierra Norte de Puebla: Estudio de caso (Doctoral thesis). Universidad Complutense, Madrid, Spain. Retrieved from http://eprints.ucm.es/12025/1/T32599.pdf.

Rojas, Olga. (2000). La paternidad y la vida familiar en la ciudad de México, un acercamiento cualitativo al papel desempeñado por los varones en los ámbitos reproductivo y doméstico, (Doctoral thesis). Centro de Estudios Demográficos y de Desarrollo Urbano, El Colegio de México, Mexico.

Salguero, Alejandra. (2014). Identidad masculina. Elementos de análisis en el proceso de construcción. Mexico: Facultad de Estudios Superiores Iztacala, Universidad Nacional Autónoma de México.

Salguero, Alejandra. (2013) Masculinidad como configuración dinámica de identidades. En Juan Ramírez \& José Cervantes (Coords.), Los hombres en México, veredas recorridas y por andar. Una mirada a los es- tudios de género de los hombres, las masculinidades (pp. 37-52). Mexico: Centro Universitario de Ciencias Económicas Administrativas y Academia Mexicana de Estudios de Género de los Hombres, A.C.

Salguero, Alejandra. (2007). Preguntarse cómo ser padre, es también preguntarse cómo ser hombre: reflexiones sobre algunos varones. In Ana Amuchástegui \& Ivonne Szasz (Coords.), Sucede que me canso de ser hombre... Relatos y reflexiones sobre hombres y masculinidades en México (pp. 563-599). Mexico: El Colegio de México.

Salguero, Alejandra. (2002). Significado y vivencia de la paternidad en el proyecto de vida de los varones (Doctoral thesis). Facultad de Ciencias Políticas y Sociales, Universidad Nacional Autónoma de México, Mexico.

Salguero, Alejandra \& Pérez, Gilberto. (2011). Dilemas y conflictos en el ejercicio de la maternidad y la paternidad. Mexico: Facultad de Estudios Superiores Iztacala, Universidad Nacional Autónoma de México.

Salguero, Alejandra \& Pérez, Gilberto. (2008). La paternidad en los varones: Una búsqueda de identidad en un terreno desconocido. Algunos dilemas, conflictos y tensiones. Revista Internacional de estudios sobre masculinidades, 3(4), 1-18.

Seidler, Victor. (2000). La sinrazón masculina. Masculinidad y teoría social. Mexico: Programa Universitario de Estudios de Género y Centro de Investigaciones y Estudios Superiores en Antropología Social, Universidad Nacional Autónoma de México.

Turner, Terence. (1999). Indigenous and culturalist movements in the contemporary global conjunture. In Francisco Fernández (Ed.), Las identidades y las tensiones culturales de la modernidad: homenaje a la Xeración Nós (pp. 52-72). Santiago de Compostela: Asociación Gallega de Antropología.

Valdés, Teresa \& Olavarría, José. (1998). Ser hombre en Santiago de Chile: a pesar de todo, un mismo modelo. En Masculinidades y equidad de género en América Latina (pp. 12-35). Santiago de Chile: FLACSO.

Viveros, Mara. (2000). Paternidades y masculinidades en el contexto colombiano contemporáneo, perspectivas teóricas y analíticas. In Norma Fuller (Ed.), Paternidades en América Latina (pp. 90-128). Peru: Fondo Editorial de la Pontificia Universidad Católica del Perú.

Weber, Max. (1988). Sobre la teoría de las ciencias sociales (José Chávez, Trans.). México: Edición La red de Jonás. (Original work published in 1969).

Wenger, Etienne. (2001). Comunidades de práctica. Aprendizaje, significado e identidad (Enís Sánchez, Trans.). Spain: Paidós. (Original work published in 1998). 